\title{
THE SENSE OF COHERENCE IN A GROUP OF PATIENTS WITH AN IMPLANTED CARDIOVERTER-DEFIBRILLATOR
}

\author{
Agata Reczek ${ }^{1, A, B, C, D, F}$, Justyna Wojdyła-Piekarz ${ }^{2, B, E}$, Ewa Kawalec-Kajstura ${ }^{1, B, E, F}$
}

'Department of Internal and Community Nursing, Institute of Nursing and Midwifery, Faculty of Health Science, Jagiellonian University Medical College, Krakow, Poland 2Department of Electrocardiology, The John Paul II Hospital, Krakow, Poland

Authors' contribution:

A. Study design/planning $\bullet$ B. Data collection/entry $\bullet$ C. Data analysis/statistics $\bullet$ D. Data interpretation $\bullet$ E. Preparation of manuscript $\bullet$ F. Literature analysis/search $\bullet$ G. Funds collection

\author{
Address for correspondence: \\ Agata Reczek \\ Department of Internal and Community \\ Nursing \\ Institute of Nursing and Midwifery \\ Faculty of Health Science \\ Jagiellonian University Medical College \\ 25 Kopernika St. \\ 31-501 Krakow, Poland \\ e-mail: agata.reczek@uj.edu.pl \\ SUBMITTED: 04.12 .2019 \\ ACCEPTED: 02.01.2020 \\ DOl: https://doi.org/10.5114/ppiel.2019.92540
}

\begin{abstract}
Introduction: The sense of coherence has a clear influence on the functioning of all spheres of life. The sense of coherence marks the position of an individual on the health-disease continuum.

Aim of the study: The assessment of the sense of coherence in a group of patients with an implanted cardioverterdefibrillator (ICD).

Material and methods: Patients with ICDs participated in the study. The study was conducted in a group of 140 patients. Most of them were men. In the study, the authors' own survey and the A. Antonovsky Life Orientation Questionnaire (SOC-29) were used, and medical documentation was analysed. The collected data were subjected to statistical analysis.

Results: The average score of SOC points was 132.41 (SD = 14.85). Age, professional activity, and financial situation had a statistically significant influence on the total sense of coherence. These variables and the marital status of the respondents had a significant influence on the sense of manageability. The sense of comprehensibility was significantly influenced only by the financial situation. The sense of coherence did not depend on sex, place of residence, living with, or without other family members, education, or support of other people.

Conclusions: In the study group only a few sociodemographic variables had a statistically significant impact on the sense of coherence and its components. No relationship between the analysed variables and the sense of meaningfulness was revealed. None of the analysed clinical variables had any significant influence on the sense of coherence and its components.

Key words: comprehensibility, manageability, meaningfulness, sense of coherence, implantable cardioverter-defi-
\end{abstract} brillator.

\section{INTRODUCTION}

The sense of coherence "reflects a person's view of life and capacity to respond to stressful situations. It is a global orientation to view life as structured, manageable, and meaningful. It is a personal way of thinking, being, and acting, with an inner trust, which leads people to identify, benefit, use, and re-use the resources at their disposal" [1, p. 95].

There are three basic components of the sense of coherence: comprehensibility, manageability, and meaningfulness $[2,3]$. These components tend to be found in certain relative strengths with each other. The most important is meaningfulness. If it is strong, the other components also have a rising tendency, but when it is weak, the other components also tend to have a falling tendency. People whose sense of coherence is strong show a much more significant strength of the previously mentioned components, contrary to people with a weak sense of coherence. The sense of coherence has a clear influence on the functioning of all spheres of life [3]. If it is strong, it facilitates the use of resources during the process of stress management. People with a high sense of coherence show a pragmatic attitude to life, and the problems they encounter are usually seen by them as a challenge. It is easier for them to control and express the emotions they experience, and they try not to let them transform into tension and stress. The sense of coherence marks the position of an individual on the health-disease continuum 
[2]. That is why the evaluation of the sense of coherence in chronic ailments seems to be very significant. Included among such ailments are diseases of the circulatory system, which, not infrequently, are treated by means of implantable devices, such as an implantable cardioverter-defibrillators (ICD). ICDs are electronic devices whose basic function involves the detection and disruption of the ventricular arrhythmia, such as ventricular fibrillation (VF) or ventricular tachycardia (VT). An ICD also functions as a heart stimulator. It may also be used as an element of cardiac resynchronisation therapy with a cardioverter-defibrillator (CRT-D) [4]. An ICD is a device that recognises and stops arrhythmia by a painless antiarrhythmic stimulation and by means of intracardiac high-energy discharge (defibrillation and cardioversion), while its Holter function makes it possible to record the registered arrhythmias, control the correctness of episode detection, and evaluate the effectiveness of therapeutic interventions [5].

The implantation of the cardioverter-defibrillators is the most effective preventive measure for sudden cardiac death. They can be both used as primary and secondary preventive measures [5]. The primary prevention concerns patients who have never experienced sudden cardiac arrest or haemodynamically unstable VT but are within the group of patients with a high risk of arrhythmic death. Secondary prevention concerns patients who have previously experienced sudden cardiac arrest [4].

As a consequence of the increasing number of patients with ICD, it seems important to conduct a study concerning various spheres of life of patients in this patient group.

\section{AIM OF THE STUDY}

The evaluation of the sense of coherence in a group of patients with an implanted cardioverter-defibrillator.

\section{MATERIAL AND METHODS}

Patients with an implanted cardioverter-defibrillator participated in the study. The patients were under the care of a cardiology outpatient clinic in the Małopolska Region. The study was conducted in a group of 140 patients. All patients were adults, and they signed an informed consent form to participate in the study. The condition was that the patient had to have a cardioverter-defibrillator for a period of no less than six months from the day of implantation. The presented study shows one of the aspects of project K/ZDS/005446, including selected aspects of the functioning of patients with an implanted cardioverter-defibrillator. The study was conducted from October 2015 until November 2016, commencing only after the agreement of the Jagiellonian University Bioethical Commission had been obtained.
A diagnostic survey was used in the study. Medical documentation was also analysed according to the study criteria. In the study the article authors' own survey and the A. Antonovsky Life Orientation Questionnaire (SOC-29) were used (Polish version). The authors' survey included basic sociodemographic data such as sex, age, home town, marital status, living with other family members or alone, education, professional activity, financial situation, and the support of other people. Primary and secondary prevention of sudden cardiac death were included in the medical documentation analysis as well as the number of years that had passed since the first ICD implantation procedure, chronic diseases of other systems, and the presence of ischaemic heart disease or heart failure were isolated.

The SOC-29 survey contains 29 questions, which form three sub-scales (comprehensibility, manageability, and meaningfulness). Obtaining a high score means a strong sense of coherence.

The collected study results were statistically analysed with the significance level of 0.05 . The analysis of the quantitative variables was conducted by calculating the mean, the standard deviation, the median, quartiles (Q1 and Q3), and the minimum and maximum values. Student's t-test, Spearman correlation coefficient, Mann-Whitney $U$ test, Kruskal-Wallis test, and ANOVA were used in the statistical analyses. A post-hoc tests was also conducted. The analysis of the research material was conducted in the $\mathrm{R}$ program, version 3.3.2.

\section{RESULTS}

Men accounted for the vast majority of the study group $(77.14 \%)$. The percentage of women in the study group was only $22.86 \%$. The respondents' mean age was 61.06 years $(S D=16.36)$; median 65 years. Most members of the study group were married (66.43\%), followed by single people $-16.43 \%$, widowed $-13.57 \%$, and divorced $-3.57 \%$. $27.14 \%$ of the members of the study group had a university degree, $33.57 \%$ finished high school, 30.00\% finished a vocational school, and $9.29 \%$ had only elementary education. The vast majority of the respondents lived in a city (69.28\%) while $30.00 \%$ of the respondents lived in the country. No information about the place of residence was obtained from $0.71 \%$ of the respondents. The vast majority $(80.71 \%)$ of the respondents lived with other family members, while $19.29 \%$ lived alone. $85.00 \%$ of the respondents declared that they were receiving support from other parties. More than half (52.86\%) indicated their spouse to be their main support. $49.29 \%$ declared receiving support from their children, and $13.57 \%$ declared support of their brothers and sisters. The other patients (14.29\%) declared having no support. No data was obtained from $0.71 \%$ 
of the respondents. $60.00 \%$ of the respondents were retired, and $18.57 \%$ received a disability pension. Only $17.86 \%$ of the respondents were still professionally active. The other patients gave various different answers. The financial situation was evaluated as good by $65 \%$ of the respondents, and $2.86 \%$ evaluated their financial situation as very good. The financial situation was difficult to evaluate for $23.57 \%$ of the respondents, while $7.86 \%$ evaluated it as bad. $0.71 \%$ gave no answer.

Throughout the analysis of the SOC-29 survey it was determined that the average score obtained by the respondents was 132.41 points $(S D=14.85)$. The score varied within the range of 94 to 172 points. In the next stage the components of the sense of coherence (comprehensibility, manageability, and meaningfulness) were evaluated (Table 1).

\section{The sense of coherence and the selected variables}

A relationship between the selected variables with the sense of coherence and its components was noted during the analysis. It was determined that age significantly influences the sense of coherence and its component, manageability. The correlation between age and the sense of coherence and manageability was positive (Table 2).

Further analysis of the data showed that marital status had a significant influence on the respondents' manageability. Score of manageability was significantly higher in group of widowed people (Table 3).

It was also found that professional activity had a significant impact on the sense of coherence and its component: manageability. The post-hoc test showed

Table 1. The sense of coherence in ICD patients

\begin{tabular}{lccccccc}
\hline Components & Mean & SD & Median & Min. & Max. & Q1 & Q3 \\
\hline Comprehensibility & 44.49 & 6.79 & 44 & 27 & 63 & 40 & 50 \\
\hline Manageability & 49.24 & 6.93 & 49 & 34 & 65 & 44 & 54 \\
\hline Meaningfulness & 38.68 & 5.49 & 38 & 25 & 50 & 35 & 43 \\
\hline SOC - total score & 132.41 & 14.85 & 131.07 & 94 & 172 & 121 & 144 \\
\hline
\end{tabular}

Table 2. The sense of coherence and the respondents' age

\begin{tabular}{lcccc}
\hline Components & \multicolumn{3}{c}{ Age correlation } \\
\cline { 2 - 5 } & $\begin{array}{c}\text { Correlation } \\
\text { coefficient }^{*}\end{array}$ & $p$ & $\begin{array}{c}\text { Dependence } \\
\text { direction }\end{array}$ & $\begin{array}{c}\text { Dependence } \\
\text { force }\end{array}$ \\
\hline Comprehensibility & 0.126 & 0.138 & - & - \\
\hline Manageability & 0.18 & 0.033 & positive & very weak \\
\hline Meaningfulness & 0.055 & 0.52 & positive & very weak \\
\hline SOC - total score & 0.172 & 0.042 & &
\end{tabular}

*Spearman correlation coefficient

Table 3. The sense of coherence and the respondents' marital status

\begin{tabular}{|c|c|c|c|c|c|c|c|c|c|c|}
\hline Components & Marital status & $N$ & Mean & SD & Median & Min. & Max. & Q1 & Q3 & $p^{*}$ \\
\hline \multirow{2}{*}{ Comprehensibility } & Married (B) & 93 & 44.41 & 6.74 & 44 & 27 & 58 & 40 & 50 & \\
\hline & Widowed (C) & 19 & 45.07 & 5.77 & 47 & 33 & 52 & 41.5 & 49.5 & \\
\hline \multirow[t]{2}{*}{ Manageability } & Single/divorced (A) & 28 & 47.82 & 7.6 & 48 & 34 & 65 & 43 & 51.25 & 0.043 \\
\hline & Widowed (C) & 19 & 52.47 & 5.1 & 53 & 43 & 62 & 49 & 55 & $C>A B$ \\
\hline \multirow[t]{3}{*}{ Meaningfulness } & Single/divorced (A) & 28 & 38.61 & 6.33 & 39 & 25 & 50 & 36 & 43.25 & 0.886 \\
\hline & Married (B) & 93 & 38.64 & 5.24 & 38 & 27 & 49 & 35 & 42 & \\
\hline & Widowed (C) & 19 & 38.96 & 5.71 & 39 & 26 & 48 & 36 & 43 & \\
\hline
\end{tabular}

*Kruskal-Wallis test; post-hoc test (Dunn test) 
that people who received a disability pension had a significantly lower sense of coherence than other respondents. In these people, component manageability was also lower than in retired people (Table 4).

The last variable that had an impact on the sense of coherence and its components was financial situation. The sense of coherence and its components: comprehensibility and manageability, had a statistically significant relation with the financial situation of the respondents. People whose financial situation was good or very good presented a higher level of sense of coherence as well as comprehensibility and manageability than other people (Table 5).

The global sense of coherence (and its components) did not depend on sex, place of residence, living with or without other family members, education, or support of other people $(p>0.05)$.

It should be noted that some selected clinical variables were also analysed. However, neither the rationale for implanting the ICD (primary or secondary prevention) nor the number of years since the first ICD implantation procedure, or presence of chronic diseases, other than the diseases of the circulatory system, had any statistically significant impact on the level of the sense of coherence and its components. No statistical significance between the sense of coherence and the presence of ischaemic heart disease or heart failure was detected either $(p>0.05)$.

\section{DISCUSSION}

After the ICD implantation patients see and experience their disease and the treatment with the device in a very individual and varied way [6]. Patients' opinions about the treatment and their belief in its effectiveness as well as their awareness of the necessity of life with the ICD are of great significance [5]. It should also be noted that the main chronic disease, the presence of the device, the need for long-term and regular check-ups in a specialist clinic, undergoing high-energy therapy, or the fear of such therapy, as well as a fear of being stigmatised and a fear of physical contacts, aesthetic discomfort after the procedure, or limitations to practicing sports or professional activity all have an impact on the overall functioning of the patient [7]. An ICD may influence various spheres of life. There are

Table 4. The sense of coherence and respondents' professional activity

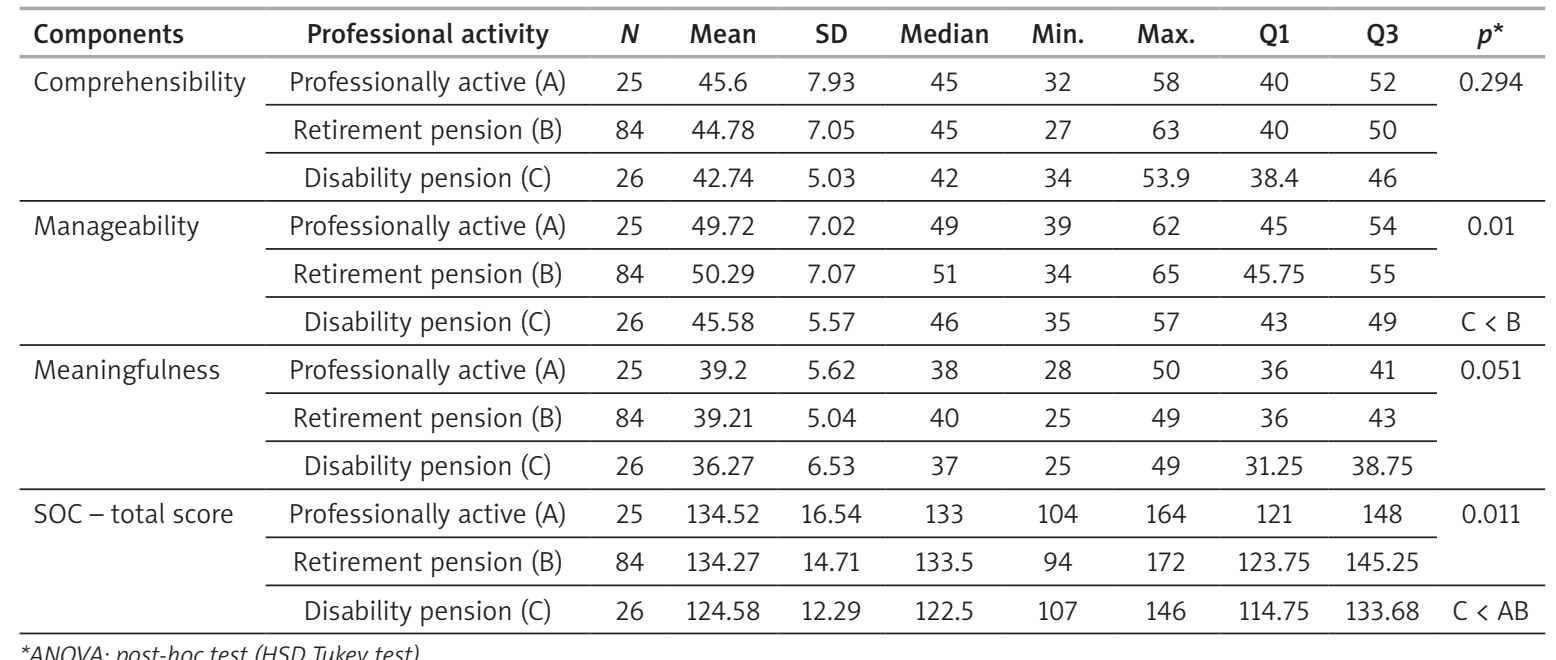

Table 5. The sense of coherence and respondents' financial situation

\begin{tabular}{lcccccccccc}
\hline Components & Financial situation & $\boldsymbol{N}$ & Mean & SD & Median & Min. & Max. & Q1 & Q3 & $p^{*}$ \\
\hline \multirow{2}{*}{ Comprehensibility } & Very good, good & 95 & 45.27 & 6.86 & 45 & 28 & 63 & 40 & 50 & \multirow{2}{*}{0.037} \\
\cline { 2 - 10 } & Difficult to define, bad & 44 & 42.69 & 6.38 & 42.5 & 27 & 53 & 38 & 48 & \\
\hline \multirow{2}{*}{ Manageability } & Very good, good & 95 & 50.31 & 6.94 & 51 & 35 & 65 & 45.5 & 55 & 0.008 \\
& Difficult to define, bad & 44 & 46.98 & 6.49 & 48 & 34 & 60 & 43 & 51 & \\
\hline \multirow{2}{*}{ Meaningfulness } & Very good, good & 95 & 38.9 & 5.36 & 38 & 26 & 50 & 35 & 43.5 & \multirow{2}{*}{0.449} \\
\cline { 2 - 10 } & Difficult to define, bad & 44 & 38.14 & 5.85 & 38 & 25 & 49 & 34.75 & 42 & \\
\hline \multirow{2}{*}{ SOC- total score } & Very good, good & 95 & 134.47 & 15.02 & 134 & 103 & 172 & 123 & 145.95 & 0.014 \\
\cline { 2 - 10 } & Difficult to define, bad & 44 & 127.8 & 13.7 & 126.5 & 94 & 151 & 118.75 & 136.5 & \\
\hline
\end{tabular}

*Student's t-test 
patients who experience fear and depression. These disorders are mostly expressed in patients with unjustified and/or electrical discharges. The level of stress they experience may differ, and post-traumatic stress syndrome may occur [8]. The chronic stress that some people with an ICD experience may lead to problems in their social and professional life [9]. It should be emphasised that a chronic disease, its duration, number of hospitalisations, and quality of social relations may influence patients' emotional condition. Kurowska et al. indicate that the differences in the range of the sense of coherence may be seen in the specific character of the ailment [10].

This paper presents a study conducted on a group of adult patients after cardioverter-defibrillator implantation. The mean value of the sense of coherence obtained by the respondents was 132.41 points. The typical score in the analysed group ranged between 121 and 144 points. The mean value fits the norms provided by Antonovsky (130-160). However, a considerable portion of the results were below these values. This is significant because, in their adaptation to the disease, people with lower SOC values may need some additional support [3]. Similar results (mean $=131.41$ ) were obtained by Milaniak, who also carried out her study on cardiological patients after heart transplantation [11]. A significant percentage of patients scored less than 130 points in those studies. Much higher scores were obtained by patients after the implantation of an artificial pacemaker (mean $=155.69)$ [12].

In the authors' own studies, the scores for components of the sense of coherence varied, and they were: 44.49 points for comprehensibility, 49.24 points for manageability, and 38.68 points for meaningfulness. Kurowska et al. indicated that meaningfulness is an important component of the sense of coherence, and they also argued convincingly that for the patients it was worth getting involved and realising plans [13].

A statistically significant influence of some selected variables on the overall score of the sense of coherence and its components was stated in our own study. One of these variables was age. With age, the respondents' sense of coherence and manageability was increasing. It can be said that the sense of coherence is a good predictor for the future, and its increase is consequently connected with positive ageing [14]. People whose sense of coherence is at a high level can cope better with the difficulties of old age [15]. In the studies of Kurowska et al. elderly people gave the highest scores to the sense of comprehensibility, then manageability, and finally meaningfulness [13]. Age was also significant in the studies of cardiological patients conducted by Toukhsati et al. [16]. It also influenced the sense of coherence in patients after pacemaker implantation [12]. However, as may be concluded from the literature, taking the sense of coherence into con- sideration, age does not always differentiate patients $[10,17,18]$, and it can also be influenced by health condition, social support, or financial situation. Fok et al. indicated that income and support from grown-up children were the predictors of a strong sense of coherence [18]. In the studies of Kocjan et al. [19], an analysis of the dependence between age and the sense of coherence showed statistically significant correlations with components of the sense of coherence only in men. On the other hand, the marital status had some impact on the sense of coherence, comprehensibility, and manageability in a group of patients after the implantation of a pacemaker [12]. Relating the data presented in the literature to our own study results, it was decided that the marital status of the respondents after the ICD implantation had a significant influence on the sense of manageability. Widowed people presented a significantly higher sense of manageability than other respondents. Professional activity was also of fundamental significance. People who were living off a disability pension presented a lower sense of coherence than the other respondents and a lower sense of manageability as opposed to the retired patients. It may be related to the respondents' financial situation, which was mentioned before. Respondents who evaluated their financial situation as very good or good had a higher sense of coherence, i.e. comprehensibility and manageability.

The author's own studies did not confirm any statistically significant relationship between the sense of coherence and its components, and sex, place of residence, living with or without other family members, education, or support of other people. Kurowska et al. claimed that sex and education level were significant in patients after a myocardial infarction [20].

Interesting findings were presented by Izdebski et al. [21], who focused on place of residence. In relation to the sense of coherence, comprehensibility, and manageability, they did not find any difference between people residing in a care home or living in their own homes. The only component for which a difference was actually indicated was the above-mentioned sense of meaningfulness. People residing in care homes had a lower sense of meaningfulness than people living at home. It was noticed in the Piegza studies [17] that lack of social support and lower level of education was related to lower level of the sense of coherence. A positive influence of marriage, living with family, and good social relations are indicated in the literature as important aspects with an impact on the sense of coherence [17, 22].

Another significant element, analysed in the author's own studies, was the respondents' health condition. It was found that the rationale for implanting the ICD (primary or secondary prevention), the number of years since the first implantation procedure, 
and the presence of chronic diseases affecting other body systems did not have any statistically significant influence on the level of the sense of coherence. The selected clinical units of ischaemic heart disease and heart failure did not significantly influence the sense of coherence, either. In other described studies the duration of the disease [10], the number of years since the implantation of a pacemaker [12], and undergone cardio-surgical interventions [19] also did not significantly influence the sense of coherence. Kocjan et al. [19] indicated that the cumulative impact of additional ailments, other than cariological diseases, has an influence on the sense of coherence and its components, although statistically significant differences were found in women only. On the other hand, having done a study of female patients who underwent coronarography, Piegza et al. [17] decided that patients without significant coronary artery stenosis had a lower sense of comprehensibility before and after coronarography and lower sense of manageability after coronarography in comparison to a group of patients with significant atherosclerotic lesions.

Overall, it can be stated that there exists a range of various factors that influence the sense of coherence, some in a statistically significant way, some not.

\section{CONCLUSIONS}

In the study group, the mean value of the sense of coherence was contained in the lower norm limit indicated by Antonovsky. Only few socio-demographic variables had a statistically significant impact on the sense of coherence and its components. Respondents' age, professional activity, and financial situation had some statistically significant influence on the total sense of coherence. These variables and the respondents' marital status had a significant impact also on the sense of manageability whereas the sense of comprehensibility was significantly influenced only by respondents' financial situation. No relationship between the analysed variables and the sense of meaningfulness was revealed. Unfortunately, none of the analysed clinical variables had any significant influence on the sense of coherence and its components.

\section{Disclosure}

The authors declare no conflict of interest.

\section{References}

1. Eriksson M. The sense of coherence in the salutogenic model of health. In: Mittelmark MB, Sagy S, Eriksson M, et al. (eds.). The Handbook of Salutogenesis [Internet]. Springer, Cham 2017; 91-96. https://www.ncbi.nlm.nih.gov/books/NBK435812/ pdf/Bookshelf_NBK435812.pdf (accessed: 28 Nov 2019).

2. Ogińska-Bulik N. Psychologiczne zasoby sprzyjające zdrowiu. In: Woynarowska B (ed.). Edukacja zdrowotna. Wydawnictwo Naukowe PWN, Warszawa 2017; 53-54.
3. Rynkiewicz-Andryśkiewicz M, Andryśkiewicz P, Curyło M, et al. Analiza przydatności oceny poziomu poczucia koherencji w chorobach somatycznych i psychicznych. Przegląd Med Uniw Rzesz i Nar Inst Leków w Warszawie 2014; 4: 365-374.

4. Mazurek M, Lenarczyk R, Kowalski O, Kalarus Z. Co lekarz praktyk powinien wiedzieć o automatycznym kardiowerterze-defibrylatorze? Chor Serca i Naczyń 2014; 11: 128-137.

5. Kochańska, A, Zarzycka B. Pacjent z implantowanym kardiowerterem-defibrylatorem serca (ICD). Czy można się przyzwyczaić do wyładowań kardiowertera-defibrylatora? For Med Rodz 2010; 4: 10-16.

6. Kuśmierz M, Wleklik M, Uchmanowicz I, et al. Wpływ kardiowertera-defibrylatora na jakość życia - przegląd badań. Folia Cardiol 2016; 11: 28-36.

7. Karczmarewicz G, Ziavina Y, Michalik J, et al. Dlaczego należy diagnozować depresję u chorych z implantowanym układem do elektroterapii serca? Folia Cardiol 2018; 13: 274-278.

8. Priori SG, Blomström-Lundqvist C, Mazzanti A, et al. Wytyczne ESC dotyczące postępowania u pacjentów z komorowymi zaburzeniami rytmu oraz zapobiegania nagłym zgonom sercowym w 2015 roku. Kardiol Pol 2015; 73: 795-900.

9. Mańkowska-Załuska B, Nowek A, Topolska E, et al. Problemy psychologiczne pacjentów po implantacji kardiowerteradefibrylatora serca. Folia Cardiol 2015; 10: 342-347.

10. Kurowska K, Żegarska K, Głowacka M, et al. Poczucie koherencji u pacjentów ze schorzeniami reumatycznymi. Psychogeriatria Pol 2009; 6: 9-14.

11. Milaniak I. Poczucie koherencji a jakość życia pacjentów po przeszczepieniu serca. Probl Pielęgniarstwa 2016; 24: 199-205.

12. Reczek A, Pawelec I, Malinowska-Lipień I, et al. Poczucie koherencji u chorych po implantacji stymulatora serca. Hygeia Public Heal 2014; 49: 353-358.

13. Kurowska K, Orzoł B. Poczucie koherencji a zadowolenie z życia u osób starszych. Gerontol Pol 2016; 24: 91-97.

14. Wiesmann U, Hannich HJ. A salutogenic inquiry into positive aging - a longitudinal analysis. Aging Ment Health 2018; 23: 1562-1568.

15. Zielińska-Więczkowska H, Kędziora-Kornatowska K. Determinanty satysfakcji życiowej w późnej dorosłości - w świetle rodzimych doniesień badawczych. Psychogeriatria Pol 2010; 7: 11-16.

16. Toukhsati SR, Jovanovic A, Dehghani S, et al. Low psychological resilience is associated with depression in patients with cardiovascular disease. Eur J Cardiovasc Nurs 2017; 16: 64-69.

17. Piegza M, Badura-Brzoza K, Pudlo R, et al. Poczucie koherencji w grupie kobiet poddanych koronarografii. Psychiatr Pol 2014; 48: 975-986.

18. Fok SK, Chair SY, Lopez V. Sense of coherence, coping and quality of life following a critical illness. J Adv Nurs 2005; 49: 173-181.

19. Kocjan J, Knapik A. Poczucie koherencji u pacjentów ze schorzeniami kardiologicznymi. Ann Acad Med Siles 2014; 68: 424-429.

20. Kurowska K, Wierzkowska M, Głowacka M, et al. Poczucie koherencji a style radzenia sobie chorych z przebytym zawałem mięśnia sercowego. Psychogeriatria Pol 2009; 6: 181-188.

21. Izdebski P, Polak A. Bilans życia i poczucie koherencji osób starszych w zależności od ich aktualnej sytuacji życiowej. Gerontol Pol 2005; 13: 188-194.

22. Kołtuniuk A, Podsiadły A, Jankowska-Polańska B. Poczucie koherencji a jakość życia pacjentów z niewydolnością serca. Współczesne Pielęgniarstwo i Ochrona Zdrowia 2017; 6: 15-18. 